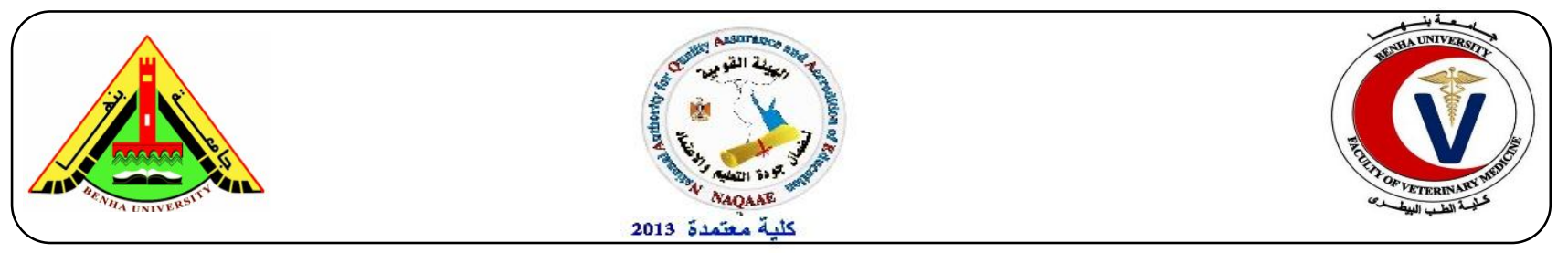

\title{
Effect of Marination on Vibrio Parahaemolyticus in Tilapia Fillets
}

\author{
Hemmat M. Ibrahim, M. ${ }^{1}$, Reham A. Amin ${ }^{1}$, Nesreen Eleiwa, Z. ${ }^{2}$, Hanan R. M. Ghanaym, ${ }^{2}$ \\ ${ }^{1}$ Food Hygiene Department, Faculty of Veterinary Medicine, Benha University , ${ }^{2}$ Food Control \\ Department, Animal Health Research Institute, Tanta Branch.
}

\section{A B S T R A C T}

Foodborne diseases affect millions of people each year. To reduce the incidence of bacterial foodborne pathogens such as $V$. parahaemolyticus, more effective treatment methods are needed. Accordingly, the effect of marinating fish fillets with lemon juice $50 \%$, thyme powder $4 \mathrm{~g} / \mathrm{kg}$ and pomegranate peel extract (PPE) $(1 \% \mathrm{v} / \mathrm{w})$ against $V$. parahaemolyticus were studied . The prepared marinades were artificially added to fish fillet samples inoculated with $V$. parahaemolyticus then hold in refrigerator at $4^{\circ} \mathrm{C}$ and examined every day. Results indicated that the lemon juice decreased the count of $V$. parahaemolyticus from $\log 8.99 . \pm 0.02 \mathrm{cfu} / \mathrm{g}$ to $\log \leq 1 \mathrm{cfu} / \mathrm{g}$ at fourth day by reduction $\% 100$, while thyme powder reduced the count to $4.86 \pm 0.51 \mathrm{log} \mathrm{cfu} / \mathrm{g}$ at fifth day by reduction $\% 88.5$. Finally, PPE decreased the count to $\log 4.89 \pm 0.38 \mathrm{cfu} / \mathrm{g}$ at fifth day by reduction $\% 76.3$. Thus, lemon juice was the most effective agent against $V$. parahaemolyticus as killing all the bacteria within four days of incubation.

Keywords: Vibrio parahaemolyticus., marination, lemon, thyme, Pomegranate

\section{(http://www.bvmj.bu.edu.eg) $\quad$ (BVMJ-34(2): 234-245, 2018)}

\section{INTRODUCTION:}

Fish and seafood constitute an important food component for a large section of world population. They come after meat and poultry as stable animal protein food where fish forms a cheap source of protein (Bakr et al., 2011).

Long cooking periods (roasting and frying) can cause the formation of tricyclic amines in the foodstuffs. These chemicals are considered as carcinogenic and may be dangerous for public health. In order to prevent the occurrence of this carcinogenic substances in fish meat, it can be processed with organic acids and salt either during cooking at reduced cooking temperatures or without any heat application. This widely accepted hygienic preservation method is known as marination (Collignana et al.,2001) 
The marinating process is one of the oldest methods of preservation of fish and other sea products (Giuffrida et al., 2007). Marinades are solutions, including sugar, spices, oil, acids (from vinegar, fruit juice, wine) and they are used to improve tenderness, juiciness, flavour and aroma and to extend shelf life of seafood, meat, poultry and vegetables (Cadun et al., 2005).

Marinated fish are typically inspired as ready-to-eat products with no heat treatment (Gram and Huss, 1996). Marinades are semipreserves; the preserving principal is the combination of acetic acid and salt. The inhibitory effects of these substances on bacteria and enzymes increase with concentration. The aim is not only to hold up the action of bacteria and enzymes, but also to tenderize or to change the taste, textural and structural properties of raw material, resulting in a product with a characteristic flavour and an extended shelf life. Marinades are stored at cooler temperatures $\left(4-6^{\circ} \mathrm{C}\right)$ keep for a long time (Gokoglu et al., 2004).

Lemon juice was very effective in inhibiting Vibrio, Enterobacter, Citrobacter spp. and E. coli (Jayana et al., 2010). Lemon essential oils also showed antioxidant activity (Kim et al., 2008).

Thyme oil is a tonic stimulant and stomachic and digestive relieves gastritis, enterocolitis and mouth thrush. It is useful for respiratory infections, asthma and bronchitis. It is effective for treating swelling provoked by gout or rheumatic problems, for joint pains, backache and sciatica. Thyme oil is also useful for urinary and vaginal infections, endometritis (candida), prostrates and vaginitis (Ratan, 2006). Thyme oil exhibits antibacterial activity and has been useful in dental practice.
Pomegranate was reported in numerous studies to have excellent antifungal, antiprotozoal, antioxidant, anticarcinogenic, anti-inflammatory and antibacterial properties (Wang et al., 2011). Pomegranate (Punica granatum L.) is known as one of the healthiest fruits due to its high phenolic content and antioxidant activity (Tabaraki et al., 2012).

Pomegranate have been reported in many studies that have antimicrobial activity against a wide range of microorganisms including Gram positive and Gram-negative bacteria (Naz et al., 2007).

The present work was planned out to study the effect of different marinades (lemon juice, thyme powder and pomegranate peel extract) on safety and shelf life of tilapia fillets samples artificially inoculated with Vibrio parahaemolyticus.

\section{MATERIAL AND METHODS:}

\subsection{Preparation of bacterial strain: -}

Vibrio

parahaemolyticus (NCTC10885) pure strain was obtained from the Food Microbiology Laboratory, Animal Health Research Institute, Dokki, Egypt. The strain was maintained on tryptic soy agar slants contain $3 \% \mathrm{NaCl}$ at $4^{0} \mathrm{C}$. Loopful of Vibrio parahaemolyticus was transferred aseptically into $10 \mathrm{ml}$ of sterile alkaline peptone water with3\% $\mathrm{NaCl}$ and then incubated at $37^{\circ} \mathrm{C}$ for $24 \mathrm{hrs}$. After that Vibrio parahaemolyticus was counted by using spread plate method (FDA, 2001) to determine the concentration. The count was adjusted to $10^{7} \mathrm{cfu} / \mathrm{ml}$ (Shirazinejad and Ismail, 2010) with tube dilution methods. The number of $\mathrm{cfu} / \mathrm{ml}$ was considered as infective dose to be inoculated into fish fillet samples. 


\subsection{Preparation of fish fillet Samples:}

A grand total of $1 \mathrm{Kg}$ of fresh Tilapia fillets were purchased directly from local markets in Tanta, Gharbia governorate, Egypt. The samples were taken and transferred directly to the laboratory in an ice box under complete aseptic conditions without delay. The samples were cut into pieces and divided into five equal groups (200g of each) and placed in aseptic polypropylene trays designed for disposable food packaging.

\subsection{Preparation of Marinades:}

Marined I consists of mixture of $(100 \mathrm{ml}$ fresh lemon juice, $5.9 \mathrm{~g}$ garlic powder, $9.23 \mathrm{~g}$ table salt, $0.5 \mathrm{~g}$ turmeric, $0.15 \mathrm{~g}$ hot chili powder, $0.5 \mathrm{~g}$ black pepper and $200 \mathrm{ml}$ distilled water) were mixed well according to Siavash et al. (2016).

Marined II as Marined I but addition of thyme powder $4 \mathrm{~g} / \mathrm{kg}$ instead of lemon juice according to Daniela Istrati et al (2011).

Marined III as Marined I but addition of pomegranate peel extract (PPE) (1\% v/w) supplied from National Research Center, instead of lemon juice according to Unalan et al., (2011).

\subsection{Artificial contamination of fish fillet samples with Vibrio parahaemolyticus:}

The tilapia fillets samples $(200 \mathrm{~g})$ were inoculated with $V$. parahaemolyticus $10^{7} \mathrm{cfu} / \mathrm{ml}$ (Shirazinejad and Ismail, 2010) by pipetting the inoculum drop by drop as evenly as possible across the samples and mixed well with sterile glass rod for distribution of the inoculum and gentle rocking the samples immediately after inoculation. The inoculated tilapia fillets samples were left for $30 \mathrm{~min}$. at room temperature to allow attachment and absorption of the inoculated bacteria (Dubal et al., 2004). The contaminated samples were stored at ambient temperature $\left(30 \pm 2^{\circ} \mathrm{C}\right) . V$. parahaemolyticus count in the sample was enumerated to get the initial load before addition of marinades (Terzi and Gucukoglu, 2010).

\subsection{Challenge trials:}

The samples were divided into five groups. Group one (control -ve) in which the samples were immersed in $300 \mathrm{ml}$ distilled water only. Group two (control +ve) the samples were inoculated with $10^{7} \mathrm{cfu} / \mathrm{ml} V$. parahaemolyticus strain only and immersed in $300 \mathrm{ml}$ distilled water. Group three the samples were inoculated with $10^{7} \mathrm{cfu} / \mathrm{ml} \quad \mathrm{V}$. parahaemolyticus strain and immersed in $300 \mathrm{ml}$ of marinade $\mathrm{I}$ at a ratio of 1.5:1 (marinade: fish fillet, $\mathrm{ml} / \mathrm{g}$ ). For group four, the samples were inoculated with $10^{7} \mathrm{cfu} / \mathrm{ml} \mathrm{V}$. parahaemolyticus strain and immersed in $300 \mathrm{ml}$ of marinade II at a ratio of 1.5:1 (marinade: fish fillet, $\mathrm{ml} / \mathrm{g}$ ). For group five, the samples were inoculated with $10^{7} \mathrm{cfu} / \mathrm{ml} V$. parahaemolyticus strain and immersed in $300 \mathrm{ml}$ of marinade III at a ratio of 1.5:1 (marinade: fish fillet, $\mathrm{ml} / \mathrm{g}$ ). Marinades covered all surface of tilapia fillets samples. The tilapia fillets samples were gently agitated or pressed with a sterile spatula to ensure immersion in the marinade. Care was taken to ensure that the solid components of the marinades were distributed as evenly as possible both within and between trays.

All the trays were properly labelled, stored at $4^{\circ} \mathrm{C}$ and examined every day for sensory analysis (colour, odour and texture) according to (Hemin, 2013) and Vibrio parahaemolyticus count until spoilage of the examined samples occurred, according to (FDA, 2001). All the above experiment was performed in triplicate (three times). 
2.6. Sensory examination (colour, odour and texture): -

It was conducted during storage according to Hemin (2013).

\subsection{Bacteriological Analysis:}

Ten grams from each sample were taken under aseptic condition to sterile homogenizer containing $90 \mathrm{ml}$ peptone water with $3 \% \mathrm{NaCl}$ then the contents were homogenized at 4000rpm for $2.5 \mathrm{~min}$. after that the mixture was allowed to stand for 6 min. at room temperature under aseptic condition. The content of the flask was thoroughly mixed and $1 \mathrm{ml}$ was transferred into separated tubes containing $9 \mathrm{ml}$ of sterile alkaline peptone water with3\% $\mathrm{NaCl}$, from which tenfold serial dilutions up to $10^{-10}$ were prepared. From the prepared samples $0.1 \mathrm{ml}$ from each prepared serial dilutions were spread plated with a glass spreader on Thiosulfate citrate bile and sucrose agar (TCBS) then incubated at $37^{\circ} \mathrm{C}$ for $24 \mathrm{hrs}$ (Thatcher and Clark, 1978). The rounded colonies $2-3 \mathrm{~mm}$ in diameter, with green and /or blue centers were counted and expressed as colony forming units $(\log \mathrm{cfu} / \mathrm{g})$.

\subsection{Statistical analysis:}

The data was statistically treated by one-way ANOVA using SPSS program for windows (Version 17) (SPSS Inc. Chicago, IL and USA) and Duncan's post hoc test with $\mathrm{p}<$ 0.05 considered to be statistically significant (Knapp and Miller 1992).

\section{RESULTS:}

The results obtained in table (1) showed that the scores of overall acceptability in case of using lemon juice $5 ; 4.66 \pm 0.33 ; 4.33 \pm 0.33 ; 3.66 \pm 0.33 ; 3.33 \pm 0.33$; $3.16 \pm 0.16$ and $2.66 \pm 0.33$ at zero day, $1^{\text {st }}$ day, $2^{\text {nd }}$ day, $3^{\text {rd }}$ day, $4^{\text {th }}$ day, $5^{\text {th }}$ day and $6^{\text {th }}$ day of the storage period at $4^{\circ} \mathrm{C}$, respectively. While, in case of using thyme powder the scores was5; $\quad 4.33 \pm 0.33 ; \quad 3.66 \pm 0.33 ; \quad 3.33 \pm 0.33$; $2.83 \pm 0.16 ; 2.50 \pm 0.50$ and $1.66 \pm 0.33$ at the same period of storage, respectively. In case of using PPE, the score was 5; 3.66 \pm 0.33 ; $3.33 \pm 0.33 ; \quad 2.66 \pm 0.33 ; \quad 1.66 \pm 0.33$ and $1.33 \pm 0.33$ at the same period of storage, respectively. Comparing with the score of overall acceptability in the control sample which was 5 , 3and 1 after zero day, $1^{\text {st }}$ day and $2^{\text {nd }}$ day of the storage period at $4^{\circ} \mathrm{C}$ respectively.

Table (2) revealed $V$. parahaemolyticus counts $(\log \mathrm{cfu} / \mathrm{g})$ in tilapia fillet samples treated with different marinades. The initial counts of $V$. parahaemolyticus in tilapia fillet samples was $8.99 \pm 0.02 \log \mathrm{cfu} / \mathrm{g}$. Such count of $V$. parahaemolyticus slightly decreased to $6.78 \pm 0.78 ; 7.94 \pm 0.53$ and $8.37 \pm 0.11 \mathrm{log} \mathrm{cfu} / \mathrm{g}$ respectively, after treatment with lemon juice, thyme powder and PPE, respectively. Comparing with $V$. parahaemolyticus count in the control-ve and +ve samples which were 3.28. \pm 1.76 and $9.14 \pm 0.49 \quad \log \mathrm{cfu} / \mathrm{g}$, respectively. On the $1^{\text {st }}$ day at refrigeration storage $\left(4 \pm 1^{\circ} \mathrm{C}\right)$ the mean value of $V$. parahaemolyticcus in control $-\mathrm{ve}$ and $+\mathrm{ve}$ samples was $2.9 \pm 1.45$ and $9.58 \pm 0.34 \mathrm{log}$ $\mathrm{cfu} / \mathrm{g}$, respectively. The mean value of $V$. parahaemolyticus were $4.33 \pm 0.33 ; 6.54 \pm 0.53$ and $6.99 \pm 0.19 \mathrm{log} \mathrm{cfu} / \mathrm{g}$, respectively. On the $2^{\text {nd }}$ day the mean counts of $V$. parahaemolyticus were $3.30 \pm 0.30 ; 6.19 \pm 0.41$ and $6.31 \pm 0.17 \log \mathrm{cfu} / \mathrm{g}$, respectively. On the $3^{\text {rd }}$ day the mean value of $V$. parahaemolyticcus were $3.20 \pm 0.20 ; 5.03 \pm 0.22$ and $5.40 \pm 0.11 \log \mathrm{cfu} / \mathrm{g}$, respectively. On the $4^{\text {th }}$ day the mean counts of $V$. parahaemolyticus were not detected; $4.86 \pm 0.51$ and $4.89 \pm 0.38 \quad \log \mathrm{cfu} / \mathrm{g}$, respectively. By the $5^{\text {th }}$ day the mean value of $V$. parahaemolyticus were not detected; 
$1.03 \pm 0.37$ and $2.13 \pm 0.81 \log \mathrm{cfu} / \mathrm{g}$ for samples treated with lemon juice, thyme powder and PPE, respectively.

Table (3) showed that the reduction percent of $V$. parahaemolyticus in tilapia fillet were $24.58 \%$; 51.83\%; 63.29\%; 64.40\%; $100 \%$ and $100 \%$ during refrigerated storage, respectively in case of treatment with lemon juice. While marinating with thyme powder reduced the growth of $V$. parahaemolyticus by $11.67 \% ; 27.20 \% ; 31.14 \% ; 44.04 \% ; 45.93 \%$ and $88.50 \%$ after zero day, $1^{\text {st }}$ day, $2^{\text {nd }}$ day, $3^{\text {rd }}$ day, $4^{\text {th }}$ day, $5^{\text {th }}$ day of refrigerated storage, respectively. Meanwhile fish fillet samples treated with PPE recorded reduction in $V$. parahaemolyticus by $6.80 \% ; 22.24 \% ; 22.90 \%$; $39.45 \% ; 45.60 \%$ and $76.30 \%$ after zero day, $1^{\text {st }}$ day, $2^{\text {nd }}$ day, $3^{\text {rd }}$ day, $4^{\text {th }}$ day, $5^{\text {th }}$ day of refrigerated storage, respectively.

Table (1): The effect of different marinades (lemon, thyme and pomegranate peel extract) on overall acceptability of artificially inoculated fish fillet samples with $V$. parahaemolyticus during cold storage at $4{ }^{\circ} \mathrm{C}$.

\begin{tabular}{|c|c|c|c|c|}
\hline $\begin{array}{l}\text { Group } \\
\text { Period }\end{array}$ & Control & $\begin{array}{l}\text { Marined1 } \\
\text { (lemon juice) }\end{array}$ & $\begin{array}{l}\text { Marined II } \\
\text { (Thyme } \\
\text { powder) }\end{array}$ & $\begin{array}{l}\text { Marined III } \\
(\mathrm{PPE})\end{array}$ \\
\hline
\end{tabular}

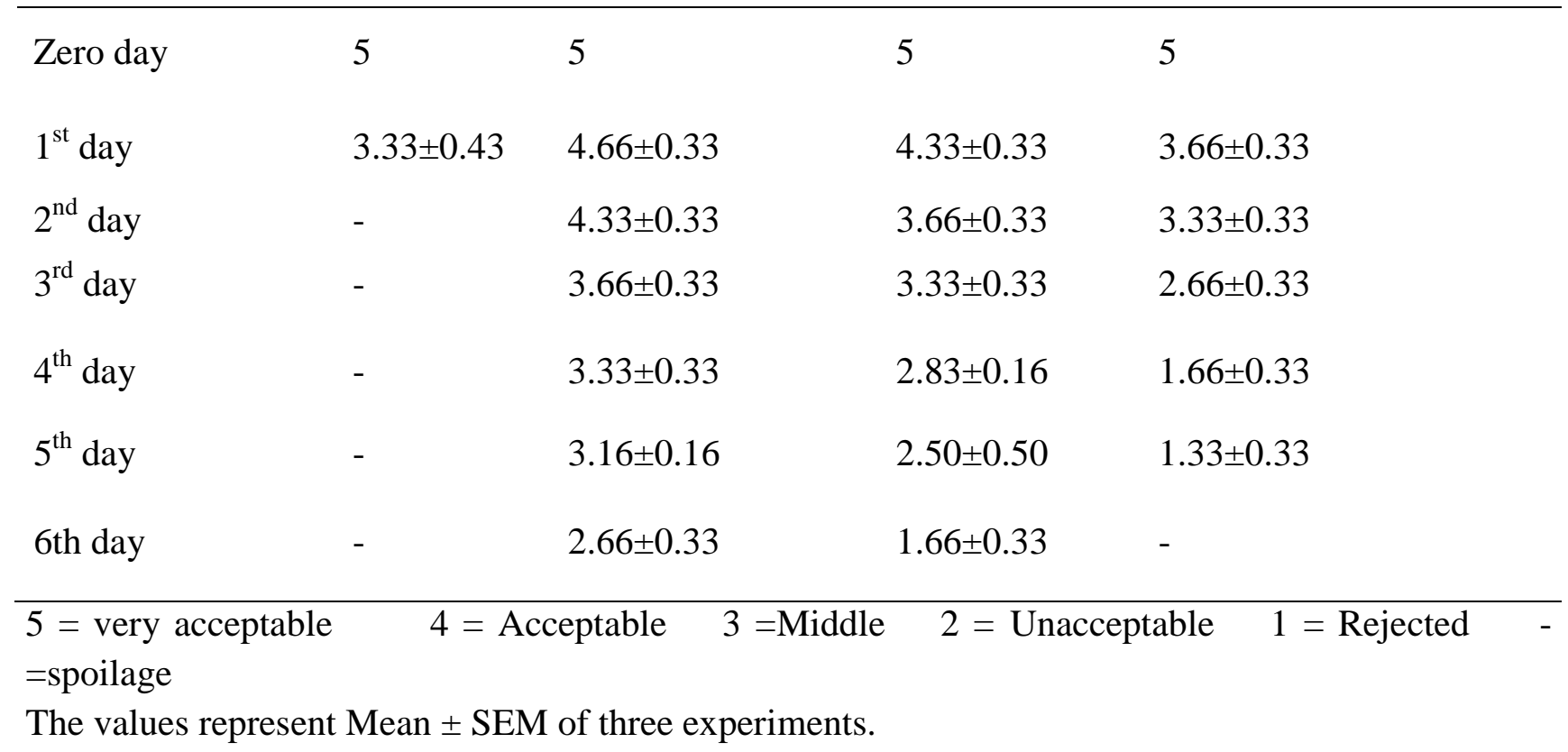


Table (2): The effects different marinades (lemon, thyme and pomegranate peel extract) on $V$. parahaemolyticus count $(\log \mathrm{cfu} / \mathrm{g})$ artificially inoculated in fish fillet samples

\begin{tabular}{|c|c|c|c|c|c|c|}
\hline Groups & Zero day & $1^{\text {st }}$ day & $2^{\text {nd }}$ day & $3^{\text {rd }}$ day & $4^{\text {th }}$ day & $5^{\text {th }}$ day \\
\hline Control -ve & $3.28 \pm 1.76^{a b}$ & $2.9 \pm 1.45$ & - & - & - & - \\
\hline Control +ve & $9.14 \pm 0.49^{a b}$ & $\begin{array}{l}9.58 \pm 0.34 \\
\text { abc }\end{array}$ & - & - & - & - \\
\hline Marined1(lemon) & $6.78 \pm 0.78^{\mathrm{a}}$ & $\begin{array}{l}4.33 \pm 0.33 \\
\text { abc }\end{array}$ & $3.3 \pm 0.3^{\mathrm{b}}$ & $3.2 \pm 0.2^{b c}$ & ND & ND \\
\hline Marined 2(Thyme) & $7.94 \pm 0.11$ & $6.54 \pm 0.53^{a b}$ & $6.19 \pm 0.41^{b}$ & $5.03 \pm 0.22 \mathrm{~b}$ & $4.86 \pm 0.51$ & $1.03 \pm 0.37^{\mathrm{a}}$ \\
\hline Marined3(PPE) & $8.37 \pm 0.53^{\mathrm{a}}$ & $6.99 \pm 0.19^{\mathrm{ab}}$ & $6.31 \pm 0.17^{\mathrm{b}}$ & $5.40 \pm 0.11^{\mathrm{c}}$ & $4.89 \pm 0.38$ & $2.13 \pm 0.81^{\mathrm{a}}$ \\
\hline
\end{tabular}

Initial load of $V$. parahaemolyticus $8.99 \pm 0.02 \mathrm{log} \mathrm{cfu} / \mathrm{g}$

The values represent Mean \pm SEM of three experiments.

Means within a column followed by different letters are significantly different $(P<0.05)$.

N.B.: (-) means samples rejected

(ND) means microorganism not detected.

Table (3): Reduction \% of $V$. parahaemolyticus count artificially inoculated into fish fillet samples treated with different marinades (lemon, thyme and pomegranate peel extract)

\begin{tabular}{|c|c|c|c|c|c|c|c|}
\hline Groups & $\begin{array}{l}\text { Zero } \\
\text { day }\end{array}$ & $1^{\text {st }}$ day & $2^{\text {nd }}$ day & $3^{\text {rd }}$ day & $4^{\text {th }}$ day & $5^{\text {th }}$ day & $6^{\text {th }}$ day \\
\hline $\begin{array}{l}\text { Marined I } \\
\text { (lemon juice) }\end{array}$ & 24.58 & 51.83 & 63.29 & 64.4 & 100 & 100 & - \\
\hline $\begin{array}{l}\text { Marined II } \\
\text { (Thyme powder) }\end{array}$ & 11.67 & 27.2 & 31.14 & 44.04 & 45.93 & 88.5 & - \\
\hline Marined III (PPE) & 6.8 & 22.24 & 22.9 & 39.45 & 45.6 & 76.3 & - \\
\hline
\end{tabular}

N.B.: (-) means samples rejected. 


\section{DISCUSSION:}

The demand for safe foods, coupled with the preference by consumers for foods free of synthetic additives, has increased the interest for natural preservatives in recent years (Moreir, et al.2007). Improvements in the shelf-life of product have an important economic impact by reducing losses attributed to spoilage and by allowing the products to reach distant and new markets. In a broad sense the ultimate goal of sensory evaluation was to predict its acceptance. Sensory analysis has become popular marketing research as well as in quality assurance and in research and development (Gouin, 2004).

The results obtained in table (1) showed that the scores of overall acceptability in case of using lemon juice was $5 ; 4.66 \pm 0.33 ; 4.33 \pm 0.33 ; 3.66$

$\pm 0.33 ; 3.33 \pm 0.33 ; 3.16 \pm 0.16$ and $2.66 \pm 0.33$ at zero day, $1^{\text {st }}$ day, $2^{\text {nd }}$ day, $3^{\text {rd }}$ day, $4^{\text {th }}$ day, $5^{\text {th }}$ day and $6^{\text {th }}$ day of the storage period at $4{ }^{\circ} \mathrm{C}$ respectively. While, in case of using thyme powder the scores was5; 4.33 \pm 0.33 ; $3.66 \pm 0.33 ; 3.33 \pm 0.33 ; 2.83 \pm 0.16 ; 2.50 \pm 0.50$ and $1.66 \pm 0.33$ at the same period of storage, respectively.

Moreover, concerning PPE, the score was $5 ; \quad 3.66 \pm 0.33 ; \quad 3.33 \pm 0.33 ; \quad 2.66 \pm 0.33$; $1.66 \pm 0.33$ and $1.33 \pm 0.33$ at the same period of storage, respectively. Comparing with the score of overall acceptability in the control sample which was 5 , 3and 1 after zero day, $1^{\text {st }}$ day and $2^{\text {nd }}$ day of the storage period at $4{ }^{\circ} \mathrm{C}$, respectively. From the obtained results there was a decline of sensorial characters after the first day of storage with clear reduction of overall acceptability values in the control samples and showed complete spoilage at $2^{\text {nd }}$ day of the storage period at $4^{\circ} \mathrm{C}$.
Furthermore, the obtained results indicated that only marination by lemon juice combated against the artificially inoculated $V$. parahaemolyticus till the $6^{\text {th }}$ day of the study and revealed the highest improvement of sensory attributes, this is because lemon contain organic acid which have antioxidative action, acid taste production, decrease of the protein content and the increase of the acidity and the free amino-acid content give the marinated fillets a characteristic texture and aroma.

So, this could be considered of highly importance indication and also a solution for the rapid decomposition of fresh fish and meat products especially those preserved by refrigeration While the sensory quality obtained by thyme powder indicated that shelf life prolonged to $5^{\text {th }}$ day, this may be due to thyme is traditionally used as flavouring agents in fish and thyme essential oil contains many flavonoids, like apigenin, aringenin, luteolin and thymonin (Penalever et al., 2005).

On the other hand, Fathy et al. (2015) reported that thyme extract has strong antimicrobial and antioxidant activity and can maintain the quality parameters and extend the shelf life of refrigerated Nile tilapia fillet for 9 days longer than control one.

While, fish fillet group treated with PPE showed somewhat acceptable improvement of sensorial characters and extended the shelf life till the $4^{\text {th }}$ day compared with control group during storage period.

Generally, sensorial characters of different treated tilapia fillet samples during cold storage $\left(4^{\circ} \mathrm{C}\right)$ were improved by using lemon juice then thyme powder and at least PPE as compared with the control ones during the same storage period. 
Spoilage characteristics develop in food as microorganisms digest the sugars, complex carbohydrates, proteins and fats of food producing undesirable effects in the food if the spoilage microorganisms grow to significant levels. Typically, the threshold level for observation of food spoilage by odour, taste or sight is not reached until the spoilage microflora exceeds about $10^{7}$ organisms/g of food. Fish microflora includes bacterial species such as Vibrio species (Gram and Huss, 2000). Microbial growth and metabolism is a major cause of fish spoilage which produce amines, biogenic amines such as putrescine, histamine and cadaverine, organic acids, sulphides, alcohols, aldehydes and ketones with unpleasant and unacceptable off-flavours (Dalgaard et al., 2006).

Many extracts and essential oils have been derived from plants and found to have antibacterial, fungicidal and insecticidal properties (Hänsel et al., 1999).

Table (2) revealed $\quad V$. parahaemolyticus counts (log cfu/g) in tilapia fillet samples treated with different marinades. The present data exhibited the potential of marinades as natural food preservative against $V$. parahaemolyticus in tilapia fillet samples. The initial counts of $V$. parahaemolyticus in tilapia fillet samples was 8.99. $\pm 0.02 \log \mathrm{cfu} / \mathrm{g}$. Such count of $V$. parahaemolyticcus slightly decreased to $6.78 \pm 0.78 ; 7.94 \pm 0.53$ and $8.37 \pm 0.11 \log \quad \mathrm{cfu} / \mathrm{g}$ respectively, after treatment with lemon juice, thyme powder and PPE, respectively. Comparing with $V$. parahaemolyticus count in the control -ve and +ve samples which were 3.28. \pm 1.76 and $9.14 \pm 0.49 \mathrm{log}$ cfu/g, respectively. The means within a column followed by different letters are significantly different $(P<0.05)$.

These finding was nearly similar to that reported by Prateek and Donald (2013) who found that reduction levels of $V$. parahaemolyticus inoculated into tilapia (Oreochromis niloticus) fillet samples and marinated with lemon juice and incubated $4{ }^{\circ} \mathrm{C}$ for 30 or $120 \mathrm{~min}$ from $>7 \mathrm{log} \mathrm{cfu} / \mathrm{g}$ to $5 \mathrm{log}$ cfu/g.

By the $1^{\text {st }}$ day at refrigeration storage $\left(4 \pm 1^{\circ} \mathrm{C}\right)$ the mean value of $V$. parahaemolyticcus in control $-\mathrm{ve}$ and $+\mathrm{ve}$ samples was $2.9 \pm 1.45$ and $9.58 \pm 0.34 \mathrm{log}$ $\mathrm{cfu} / \mathrm{g}$, respectively. The mean value of $V$. parahaemolyticcus were $4.33 \pm 0.33$ ;6.54 $\pm 0.53 \mathrm{and} 6.99 \pm 0.19 \mathrm{log} \mathrm{cfu} / \mathrm{g}$ for samples treated with lemon juice, thyme powder and PPE, respectively, the means within a column followed by different letters are significantly different $(P<0.05)$.

On the $2^{\text {nd }}$ day of refrigeration storage at $\left(4 \pm 1{ }^{0} \mathrm{C}\right)$ of treated tilapia fillets samples, the mean counts of $V$. parahaemolyticus were $3.30 \pm 0.30 ; 6.19 \pm 0.41$ and $6.31 \pm 0.17 \mathrm{log} \mathrm{cfu} / \mathrm{g}$ respectively, as well as they were acceptable from aesthetic points without off odour or discoloration. compared with the control $-\mathrm{ve}$ and +ve. samples which showed extreme discoloration and off-odour in this day of storage indicating complete spoilage.

By the $3^{\text {rd }}$ day of refrigeration storage of treated tilapia fillets samples with different marinades (lemon juice, thyme powder and PPE), the mean value of $V$. parahaemolyticcus were $3.20 \pm 0.20 ; 5.03 \pm 0.22$ and $5.40 \pm 0.11 \mathrm{log}$ $\mathrm{cfu} / \mathrm{g}$ for samples treated with lemon juice, thyme powder and PPE, respectively, the means within a column followed by different letters are significantly different $(P<0.05)$.

At the $4^{\text {th }}$ day of refrigeration storage at $\left(4 \pm 1{ }^{0} \mathrm{C}\right)$ of treated tilapia fillets samples the mean counts of $V$. parahaemolyticus were not detected; $4.86 \pm 0.51$ and $4.89 \pm 0.38 \mathrm{log} \mathrm{cfu} / \mathrm{g}$, respectively. 
By the $5^{\text {th }}$ day of refrigeration storage of treated tilapia fillets samples the mean value of $V$. parahaemolyticus were not detected; $1.03 \pm 0.37$ and 2.13 $\pm 0.81 \log \mathrm{cfu} / \mathrm{g}$ for samples treated with lemon juice, thyme powder and PPE, respectively. The means within a column followed by different letters are significantly different $(P<0.05)$.

Also, at the six day the treated samples with lemon juice become yellow in colour while samples treated with thyme powder and PPE became darken showed extreme discoloration, off-odor indicating complete spoilage.

These results were nearly similar to those reported by Daniela et al., (2011) who found that marinating by lemon enhanced shelf life at $4^{0} \mathrm{C}$ by preventing protein degradation and delay microbial spoilage.

The results showed growth of $V$. parahaemolyticus in marinated samples. As illustrated in table (3). lemon juice reduced the growth of $V$. parahaemolyticus by $24.58 \%$; $51.83 \%$; 63.29\%; 64.40\%; $100 \%$ and $100 \%$ during refrigerated storage, respectively.

Lemon contain high concentrations of citric acid, the major organic acid present in these juices, which is partly responsible for the antibacterial activity of these fruits due to contain a group of flavonoids including polymethoxy flavones, flavone glycosides and limonoids which enhance antimicrobial activity (Ladaniya, 2008).

Another study in Nigeria also showed that lemon juice (both aqueous and ethanol extracts) killed most gram positive and gramnegative bacteria at a concentration of 256 mg/mL (Aibinu et al., 2006).

While, marinating with thyme powder reduced the growth of $V$. parahaemolyticus by $11.67 \% ; 27.20 \% ; 31.14 \% ; 44.04 \% ; 45.93 \%$ and $88.50 \%$ after zero day, $1^{\text {st }}$ day, $2^{\text {nd }}$ day, $3^{\text {rd }}$ day, $4^{\text {th }}$ day, $5^{\text {th }}$ day of refrigerated storage, respectively.

Meanwhile, fish fillet samples treated with PPE recorded reduction in $V$. parahaemolyticus by $6.80 \%$; $22.24 \%$; $22.90 \% ; 39.45 \% ; 45.60 \%$ and $76.30 \%$ after zero day, $1^{\text {st }}$ day, $2^{\text {nd }}$ day, $3^{\text {rd }}$ day, $4^{\text {th }}$ day, $5^{\text {th }}$ day of refrigerated storage, respectively.

So, the present results showed that marinating with lemon juice showed maximum activity against $V$. parahaemolyticus compared with the control on fifth day of refrigerated storage at $4^{0} \mathrm{C}$.

In this study, the information given by the obtained results revealed that using marinating by lemon juice on tilapia fillets can improve its safety and extended its shelf life by enhancing sensory characters and due to their antibacterial effect against Gram negative bacteria especially Vibrio species.

\section{REFERENCES:}

Aibinu, I.; Adenipekun, T.; Adelowotan, T.; Ogunsanya, T. and Odugbemi, T. (2006): Evaluation of the antimicrobial properties of different parts of Citrus aurantifolia (lime fruit) as used locally. Afr. J. Traditional, Complementary Altern. Med., 4: 185-190.

Bakr-Wafaa, M. K.; Hazzah-Walaa,A.and Abaza-Amani, F. (2011):Detection of Salmonella and Vibrio species in some seafood in Alexandria. J. American Sci., 7(9): 663-668.

Burt, S. (2004): Essential oils: their antibacterial properties and potential applications in foods-a review. Inter $\mathbf{J}$ Food Microbiol; 94:223-53.

Cadun, A.S.; Cakli, D. and Kisla, D. (2005): A study of marination of deep water pink shrimp (Parapenaeus 
longirostris, Lucas, 1846) and its shelf life. Food Chem., 90: 53-59.

Collignan, A.; Bohuan, P.; Deumier, F. and Poligne, I. (2001): Osmotic Treatment of Fish and Meat Products. J. Food Engin. 49, 153-162.

Dalgaard, P.; Madsen, H.L.; Samieian, N. and Emborg, J. (2006): Biogenic amine formation and microbial spoilage in chilled garfish (Belone belone) effect of modified atmosphere packaging and previous frozen storage. J. Applied Microbiol., 101: 80-95. DOI: 10.1111/j.1365-2672.2006.02905. x.

Daniela, I.; Oana, C.; Aurelia, I.; Camelia,V. and Rodica,D.(2011): Study of the combined effect of spices and marination of beef meat vacuum packageg. Food Technology 35(2)7585.

Dubal, Z. B.; Paturkar, A.M.; Waskarr, V. S.; Zende, R. J. and Latha, C. (2004): Effect of food grade organic acids on inoculated S. aureus, L. monocytogens, E. coli and S. typhimurium in sheep/goat meat stored at refrigerate in temperature. $\mathrm{J}$. Meat Sci., 66:8177-821.

Fathy, A. Khalafalla; Fatma, H.M. Ali and Abdel-Rahim, H.A. Hassan (2015): Quality improvement and shelf-life extension of refrigerated Nile tilapia (Oreochromis niloticus) fillets using natural herbs Beni-Suef University, journal of basic and applied sciences, (4) $33-40$.

Food and Drug Administration (FDA) (2001): Methods for Specific Pathogens: Escherichia coli, Salmonella and Vibrio, $8^{\text {th }}$ Ed. FDA Centre for Food Safety and Applied Nutrition. Bacteriological Analytical Manual. Available at www.cfsan.fda.gov/$\underline{\text { ebam/bam-toc.html }}$
Giuffrida, A.; Ziino, G.; Orlando, G. and Panebianco, A. (2007): Hygienic Evaluation of Marinated Sea Bass and Challenge Test for Listeria monocytogenes. Vet. Res. Commun., 31 (Suppl. 1): 369-371.

Gokoglu, N.; Cengiz, E. and Yerlikaya, P. (2004): Determination of shelf life of marinated sardine (Sardina pilchardus) stored at $4^{\circ} \mathrm{C}$. Food Control, 15: 1-4.

Gouin, S. (2004): Microencapsulation: industrial appraisal of existing technologies and trends. Trends in Food Science \& Technology 15, 330 347.

Gram, L. and Huss, H.H. (1996): Microbiological spoilage of fish and fish products. Int. J. Food Microbiol., 33: 121-137.

Gram, L. and Huss, H.H. (2000): Fresh and Processed Fish and Shellfish. In: The Microbiological Safety and Quality of Foods, Lund, B.M., A.C. BairdParker and G.W. Gould (Eds.). Chapman and Hall, London, ISBN: 10: 0834213230, pp: 472-506.

Gram, L. and Huss, H.H. (2000): Fresh and Processed Fish and Shellfish. In: The Microbiological Safety and Quality of Foods, Lund, B.M., A.C. BairdParker and G.W. Gould (Eds.). Chapman and Hall, London, ISBN: 10: 0834213230, pp: 472-506.

Hänsel, R.; Sticher, O. and Steinegger, E. (1999):

PharmakognoisiePhytopharmzie, $6^{\text {th }}$ ed., SpringerVerlag, Berlin, 692-695.

Hemin, N.M. (2013): Study of some chemical, physical, sensory and bacteriological characteristic of canned chicken meat imported to Sulaymaniyah markets, Iraq. Int. J. Nuti. Metabolism., 5: 128133. 
Jayana, B.L., T. Prasai, A. Singh and K.D. Yami, 2010. Study of antimicrobial activity of lime juice against Vibrio cholerae. Scientific World, 8: 44-46.

Kim, J.E.; Kim,H.E.; Hwang, J.K.; Lee,H.J.;

Kwon, H.K. and 2008):

characteristics xanthorrhiza extract on Streptococcus mutans biofilm. J. Microbiol. (Seoul, Korea), 46: 228232.

Knapp, R.G. and Miller, M.C. (1992): Clinical epidemiology and biostatics. Pennsylvania: Harwal Publishing.

Ladaniya, M.S. (2008): Citrus fruit: Biology, technology and evaluation. USA:Academic Press/Elsevier.

Moreir, M.R.; Ponce, A.G.; Del Valle. C.E. and Roura, S.I. (2007): Effect of clove and tea tree oils on Escherichia coli O157:H7 in Blanched Spinach and minced cooked beef. Journal of Food Processing and Preservation (31) 379391.

Naz, S.; Siddiqi, R.; Ahmed, S.; Rasool, S.A. and Sayeed, S.A. (2007): Antibacterial activity directed isolation of compounds from Puni- ca granatum. J. Food Sci., (72): 341345.

Penalever, P.; Huerta, B.; Borge, C. ;Astorga, R.; Romero, R. and Perea, A. (2005): Antimicrobial activity of five essential oils against animal origin $f$ Enterobacteriaceae family. APMIS. (113) 16.

Prateek, M. and Donald, S. ( 2013): Effect of Lime Juice on Vibrio parahaemolyticus and Salmonella enterica Inactivation during the Preparation of the Raw Fish Dish Ceviche, Journal of food protection 76(6):1027-1030.
Ratan, R. (2006): Handbook of Aromatherapy. A Complete Guide to Essential and Carrier Oils, Their Application and Therapeutic Use for Holistic Health and Wellbeing. 2nd ed. Institute of Holistic Health Sciences, Mumbai; 2006. p37, 43, 48.

Raybaudi-Massilia, R.M.; Mosqueda-Melgar, J. and Martin-Belloso, O. (2006): Antimicrobial activity of essential oils on Salmonella enteritidis, Escherichia coli and Listeria innocua in fruit juices. J. Food Prot., 69: 1579-1586.

Shirazinejad, A. and Ismail, N. (2010): Effect of lactate treatments on the survival of foodborne pathogens in frozen shrimp. American J. Agri. Bio. Sci., 5:242-246.

Siavash, M.; Mehdi,Z. and Milad, C.( 2016): Effect of traditional marinating on properties of rainbow trout fillet during chilled storage. Vet. Res.Forum;7(4):295-300.

Tabaraki, R.; Heidarizadi, E. and Benvidi, A. (2012): Optimization of ultrasonic assisted extraction of pomegranate (Punica granatum L.) peel antioxidants by response surface methodology. Sep Purif Technol 98:16-23.

Terzi, G. and Gucukoglu, A. (2010): Effect of lactic acid and chitosan on the survival of $\mathrm{V}$. parahaemolyticus in mussel samples. J. Animal and Veterinary Advances, 9:990-994.

Thatcher, F.S. and Clark (1978): Microorganisms in foods. Their Significance and method of enumeration. 2nd Ed. Academic press. New York.

Ünalan, U.; Dalgaard, P. and Korel, F. (2011): Effect of pomegranate (Punica granutum) and rosemary 
(Rosmarinus officinalis L.) extracts on shelf-life for chilled Greenland halibut (Reinhardtius hippoglossoides) fillets in modified atmosphere packaging at $2{ }^{\circ} \mathrm{C}$ International Food Congress Novel
Approaches in Food Industry1, 189196.

Wang, Z., Pan, Z., Ma, H., \& Atungulu, G. G. (2011): Extract of phenolics from pomegranate peels, (43): 17-25. 